Jurnal llmu Administrasi Publik 5 (1) (2017): 18-23

Jurnal Administrasi Publik

http://ojs.uma.ac.id/index.php/publikauma

\title{
PERANAN KELUARGA BERENCANA \\ DALAM MENCEGAH KEMATIAN IBU
}

Puji Hayuningsih*

Badan Kependudukan dan Keluarga Berencana Provinsi Jawa Timur

Surabaya, Indonesia

Diterima Februari 20I7; Disetujui April 2017, Dipublikasikan Juni 2017

\begin{abstract}
Abstrak
Artikel ini bertujuan untuk mengetahui peran keluarga dalam mencegah kematian. Metode penulisan menggunakan studi pustaka dan kajian literatur terkait permasalahan yang dikaji. Hasil analisis menunjukkan bahwa tujuan utama dari program keluarga berencana harus bisa memberikan kekuatan pada wanita untuk memilih sendiri jumlah dan waktu anak-anak mereka. Hal ini juga ditujukan untuk perencana kesehatan dengan membantu mengurangi risiko melahirkan anak dan untuk menyelamatkan nyawa. Bagaimanapun ketika bergulat dengan tingginya angka kematian ibu, keluarga berencana tidak harus dilihat sebagai pengganti untuk perawatan kebidanan. Namun demikian, ini adalah godaan ketika anggaran kesehatan terbatas dan pilihan harus dibuat. Keluarga berencana dapat mengurangi jumlah risiko kematian pada perempuan akibat kehamilan. Hal tersebut tidak menjadi masalah untuk mengurangi risiko bagi mereka yang hamil. Peran keluarga berencana dalam memerangi kematian ibu adalah untuk membantu menciptakan kondisi yang sehat untuk melahirkan dan mengurangi risiko kematian terkait kehamilan bagi wanita. ini hanya salah satu bagian dari jawaban komplek untuk masalah yang kompleks.
\end{abstract}

Kata Kunci: Keluarga, peran, kematian

\begin{abstract}
Abstrak
This article aims to determine the role of families in preventing death. Writing method using literature study and literature review related issues studied. The results of the analysis show that the main purpose of the family planning program should be to give women the power to choose for themselves the amount and timing of their children. It is also aimed at health planners by helping to reduce the risk of childbirth and to save lives. However, when grappling with high maternal mortality, family planning does not have to be seen as a substitute for midwifery care. But this is a temptation when health budgets are limited and choices have to be made. Family planning can reduce the risk of death in women due to pregnancy. It is not a problem to reduce the risk for those who are pregnant. The role of family planning in combating maternal mortality is to help create healthy conditions for childbirth and reduce the risk of pregnancy-related deaths for women. this is just one part of the complex answer for complex problems.
\end{abstract}

Keywords: Family, role, death

How to Cite : Hayuningsih, P., (2017). Peranan Keluarga Berencana Dalam Mencegah Kematian lbu 5 (1): 18-23

$\begin{array}{cc}{ }^{*} \text { Corresponding author: } & \text { P-ISSN-2549-9165 } \\ \text { E-mail: Pujihayuningsih@yahoo.com } & \text { e-ISSN-2580-2011 }\end{array}$




\section{PENDAHULUAN}

Kematian maternal banyak yang disebabkan oleh fertilitas yang tidak teratur. Dalam hal ini KB mempunyai peran yang sangat penting. Akan tetapi, banyak pasangan yang sudah tidak ingin anak lagi tapi tidak menggunakan KB. Kematian maternal mencerminkan 2 (dua) hal, yaitu:

1. Resiko yang tinggi bagi perempuan yang hamil dan melahirkan

2. Fertilitas yang tinggi (frekuensi kehamilan)

KB memungkinkan perempuan untuk merencanakan kehamilan mereka dan menurunkan fertilitas dengan mengurangi kehamilan. Sehingga, KB dapat mengurangi jumlah kehamilan yang tidak diinginkan dan jumlah aborsi yang dapat mengakibatkan kematian. Akan tetapi, masalah yang paling besar adalah para perempuan ini sulit mengakses layanan kesehatan umum dan tenaga bidan/dokter, yang mengakibatkan kematian maternal. Perempuan akan beresiko tinggi terhadap kematian maternal jika:

1. Melahirkan di bawah usia 20 tahun.

2. Mempunyai anak lebih dari 4 (empat)

Kelahiran paling aman adalah pada anak

ke-2 dan ke-3. Resiko kematian maternal mulai naik pada kelahiran ke-4 dan ke-5. Perempuan yang melahirkan dengan jarak kurang dari 2 (dua) tahun beresiko $2 \frac{1}{2}$ kali lebih besar akan mengalami kematian maternal dari pada perempuan dengan interval yang lebih jauh.

Melahirkan di atas usia 35 tahun beresiko tinggi terhadap kematian maternal. KB bertujuan untuk mengurangi jumlah kematian maternal, terutama melalui penurunan fertilitas. Penurunan TFR mengurangi masa dari perempuan untuk mengalami teriko terhadap kematian maternal. Pada perempuan dengan jumlah anak banyak mempunyai resiko kematian yang lebih besar akibat kehamilannya daripada perempuan dengan jumlah anak sedikit.

Tingkat fertilitas ditentukan oleh interaksi dari berbagai faktor sosial, ekonomi, budaya, dan agama yang berpengaruh terhadap perilaku perempuan, pengetahuan, dan pemakaian kontrasepsi. Di Negara Sedang Berkembang, pendiddikan sangat berpengaruh terhadap fertilitas. Akan tetapi, hubungan antara fertilitas dengan pendidikan ini tidak selamanya linear. Demikian juga halnya dengan hubungan antara fertilitas dan wanita yang bekerja. Penurunan tingkat fertilitas biasanya mengurangi masa untuk mengalami resiko kematian yang disebabkan oleh kehamilan. Resiko kematian maternal ini terbesar berasal dari aborsi yang tidak aman dan kehamilan yang tidak diinginkan (karena perempuan dengan kehamilan yang tidak diinginkan biasanya mengabaikan kesehatannya) dan paritas yang tinggi pada perempuan berusia tua. Oleh karena itu, KB memungkinkan perempuan untuk mempunyai anak sesuai dengan pola yang relatif tanpa resiko dan menghindari kehamilan yang tidak diinginkan, dan hal ini akan berpengaruh terhadap jumlah kematian maternal.

\section{PEMBAHASAN}

Unmet need merupakan perempuan yang sudah tidak menginginkan mempunyai anak lagi, namun tidak menggunakan kontrasepsi. Akan tetapi, hal ini tidak termasuk perempuan yang ingin memberi jarak kelahiran tapi tidak menggunakan kontrasepsi maupun perempuan yang tidak menikah tapi aktif secara seksual dan ingin menghindari kehamilan. Adapun alasan perempuan yang ingin mengontrol kelahiran namun tidak memakai kontrasepsi dibagi menjadi 2 (dua) kategori, yaitu:

1. Kurangnya pelayanan

2. Penolakan dari masyarakat terhadap penggunaan kontrasepsi modern.

Walaupun di tingkat internasional KB merupakan hak asasi manusia, namun di beberapa negara dan masyarakat mempunyai pandangan yang berbeda. Beberapa negara merupakan pronatalis dan menolak penggunaan kontrasepsi karena berbagai alasan (hukum dan agama). Pada beberapa kasus, masyarakat tidak mempunyai akses terhadap pelayanan pelayanan KB karena mereka tinggal di wilayah terpencil.

Akses terhadap pelayanan KB secara tidak langsung dipengaruhi oleh familiaritas terhadap program $\mathrm{KB}$, yang diikuti oleh pengetahuan dimana pelayanan KB dapat diperoleh. Jika dibandingkan dengan masyarakat perkotaan, masyarakat di pedesaan lebih sulit untuk menerima informasi mengenai $\mathrm{KB}$ dan untuk mengakses pelayanannya, karena jarak klinik yang jauh dan suplai yang terbatas.

Pelayanan kontrasepsi yang diberikan tidak sesuai dengan kebutuhan masyarakat. Sensitivitas terhadap iklim sosial dan budaya masyarakat 
sangat penting jika menginginkan program KB menjadi efektif. Selain itu, memberi pilihan metode kontrasepsi sebanyak mungkin juga akan meningkatkan keberhasilan program KB.

Program KB identik atau banyak didominasi oleh kaum perempuan, ini berarti fakta bahwa perempuan itu juga punya hak - hak yang terabaikan, sehingga mereka terkadang berada dalam posisi yang sulit atau tidak ada pilihan. Pada sebagian masyarakat keputusan untuk melahirkan/hamil masih ditentukan oleh tetua/yang dianggap tua dalam silsilah keluarga. Sebagai contoh di Zaire misalnya di mana secara tradisional keluarga besar mengambil tanggung jawab kolektif untuk mendukung anak-anak itu adalah saudara istri (dalam kelompok matrilineal) atau ayah suami dan saudara (dalam kelompok patrilineal) yang memutuskan hal kelahiran.

jika program KB tidak mampu mengatasi permasalahan tentang pengambilan keputusan seperti ini, dan tidak meminta dukungan dari tokoh - tokoh msayarakat maka semua akan percuma. Oleh karena itu program KB akan dianggap gagal jika tidak mampu memahami keyakinan dan praktik budaya dari calon pemakai kontrasepsi/calon pelanggannya. Begitupula, jika program KB belum dapat memberikan informasi yang memadai untuk menghilangkan rasa takut serta takhayul yang masih dimiliki sebagian masyarakat maka penyediaan kontrasepsi yang belum bisa diterima secara luas akan sia-sia.

Tiga metode kontrasepsi yang sering digunakan adalah pil, perangkat intrauterine (IUD) dan kontrasepsi suntik. Ketiga kontrasepsi ini punya efek pemakain seperti terjadinya gangguan menstruasi ataupun infeksi. Hal ini mungkin menjadi salah satu kendala dalam pencapaian kesuksesan KB, terutama pada masyarakat yang masih punya ketakutan akan efek dari kontrasepsi tersebut.

Kontrasepsi yang salah satu efeknya adalah terganggunya proses menstruasi, banyak ditentang di beberapa Negara, diantaranya 50\% dari wanita yang disurvei di republik korea dan 91\% di pakistan menyatakan diri menentang metode seperti ini dengan alasan kesehatan seperti kekhawatiran bahwa kontrasepsi dapat menyebabkan penyakit yang serius, tersesat dalam tubuh, atau mempengaruhi kehidupan seksualitas mereka, mereka cenderung menghindari kehamilan dengan system kalender (periode regular siklud menstruasi).

Sebagian perempuan masih menganggap hal ini tabu sehingga mereka masih enggan untuk datang ke klinik, karena kwawatir tentang privasi mereka terganggu karena ditanya ditentang hal hal pribadi apalagi jika petugasnya adalah seorang laki - laki. Mereka menganggap pengaruh utama penggunaan kontrasepsi tentu saja adalah dari aspek agama. Beberapa pemimpin agama secara personal antipati terhadap program KB dan ini dapat mempengaruhi para pengikut mereka. Agama islam, hindu ataupun katolik juga memiliki dasar spiritual untuk menentang program KB.

Oleh karena itu program KB harus lebih peka terhadap iklim social dan budaya, agar program menjadi lebih efektif, mungkin melaui pemberian leaflet atau selebaran tentang macam metode - metode kontrasepsi, kelebihan, kekurangan serta efek samping sehingga bisa dijadikan advokasi untuk meningkatkan keberhasilan program KB .

Remaja membutuhkan perhatian khusus karena mereka masih awam dengan kontrasepsi atau program KB sehingga mereka memerlukan bimbingan khusus dalam banyak hal, karena ini masih merupakan hal baru bagi usia mereka dan status sosial. Dari sudut pandang Keluarga Berencana, remaja dapat dibagi menjadi dua kategori yaitu mereka yang sudah menikah dan mereka yang masih lajang.

Survei telah menunjukkan bahwa, di kalangan remaja yang sudah menikah di negaranegara berkembang, penggunaan kontrasepsi umumnya sangat rendah. Di Afrika, proporsi menggunakan kontrasepsi berkisar dari $1 \%$ menjadi 6,5\%, dengan Tunisia menjadi pengecualian pada lebih dari 10\%. Di Asia proporsi berkisar dari bawah $5 \%$ di Bangladesh menjadi 28\%, di Srilanka dan 29\% di Thailand. Di Amerika latin, prevalensi penggunaan kontrasepsi di kalangan remaja menikah di atas $20 \%$ di sebagian besar negara, dengan El salvador dan pengecualian Honduras berada di $8 \%$. Tingkattingkat rendah ini tidak mengherankan karena kondisi sosial yang sama bahwa pernikahan sangat awal mendukung juga awal melahirkan, adalah penting bahwa program KB melakukan upaya untuk mencapai kelompok khusus melalui pendidikan, informasi dan jasa karena risiko yang tinggi untuk ibu dan anak sebagai akibat yang 
ditimbulkan kehamilan remaja dan proses melahirkan.

Secara umum diakui bahwa meningkatkan usia perkawinan merupakan salah satu cara yang paling efektif untuk mengurangi resiko kehamilan. Ukuran ini juga cenderung untuk meningkatkan kontrasepsi di kalangan remaja yang sudah menjadi ibu dengan menunjukkan persetujuan sosial kemudian melahirkan.

Remaja yang sudah menjadi ibu dan tidak menikah butuh perhatian khusus. Masalah KB adalah salah satu yang sangat sensitif karena nada moralnya. Oleh konvensi internasional, hak untuk mendapatkan pendidikan yang memadai, informasi dan layanan untuk semua individu dan pasangan untuk memungkinkan mereka untuk mengambil tanggung jawab pribadi untuk kesuburan mereka sendiri mencakup remaja juga. Ada ketakutan luas bahwa penyediaan layanan tersebut kepada orang-orang muda di luar konteks perkawinan akan mendorong pergaulan bebas. Di beberapa Negara, konflik moral ini belum terselesaikan. Banyak remaja, melakukan jalur pengembangan pribadi yang penuh dengan bahaya.

Ada bukti bahwa aktivitas seksual di kalangan remaja yang belum menikah selalu bertambah. Data dari rumah sakit bersalin terbesar Jamaica di Kingston untuk 1976-1977, menunjukkan bahwa hampir sepertiga dari kelahiran adalah untuk remaja, kebanyakan dari mereka adalah perempuan yang masih sekolah.

Di Nigeria, juga, ada bukti dari fenomena ini : sebuah survei dari 45 sekolah menemukan bahwa hanya 12 telah terpengaruh oleh kehamilan di kalangan murid muda mereka, sementara survei 1982 sebayak 240 siswa disekolah tinggi menemukan bahwa $43 \%$ dari perempuan yang mengalami seksual aborsi merupakan indikasi lain dari aktivitas seksual di kalangan remaja yang belum menikah, dan di Sub Sahara Afrika itu, saat ini, lebih sering terjadi pada wanita muda yang belum menikah perkotaan daripada di antara wanita dari status lainnya. Penelitian di beberapa kota amerika latin di 1968-1971 menemukan bahwa tingkat antara wanita yang lebih tua pada saat itu, sedang naik lebih cepat daripada di kelompok lain dan di negara-negara di mana aborsi legal, tingkat sexualitas di kalangan remaja meningkat terus sepanjang tahun 1970-an.
Meskipun aktivitas seksual
pranikah
tampaknya meluas di banyak bagian, ketidaksetujuan dunia atau ambivalensi pada bagian dari beberapa pemerintah terhadap seluruh pertanyaan dari seksualitas remaja berarti bahwa banyak orang muda sangat tidak siap. Jika dipikir beberapa negara berkembang khususnya Filipina dan Kosta Rika yang sangat berkomitmen untuk pendidikan seks, ini absen dari kurikulum di sebagian besar negara.Terkadang Negara berkembang lainnya ini karena tidak ada ketentuan undang-undang telah dibuat untuk pendidikan seks dan telah diabaikan (seperti di Bangladesh dan sebagian besar sub Sahara Afrika) dan kadang-kadang karena telah aktif undangkan versus (seperti di banyak negara berbahasa Perancis-Afrika). kadang-kadang pendidikan seks umum diizinkan, sementara informasi spesifik mengenai kontrasepsi dilarang.

Program keluarga berencana yang bertujuan untuk menjangkau orang-orang muda harus mempertimbangkan akses mereka terhadap informasi dan keandalannya. mereka juga telah mengakui berbagai kendala terhutang perempuandan belum menikah terutama mereka yang masih legal "anak-anak" menggunakan layanan keluarga berencana.

Menurut perkiraan Negara maju, tingkat penggunaan kontrasepsi di kalangan pasangan yang sudah menikah atau kumpul kebo dengan wanita di kelompok usia reproduksi adalah 51\% bagi dunia secara keseluruhan. Ini mencerminkan pesatnya laju kenaikan dalam pertengahan 1960 berada di bawah $10 \%$. Prevalensi di negara berkembang telah mencapai 45\%, 74\% di Asia Timur, 54\% di Amerika latin, 33\% di selatan asia, dan $14 \%$ di africa.

Di negara berkembang, prevalensi kontrasepsi berkisar dari terendah $1 \%$ dari pasangan di Mauritania dan Yaman untuk 70-75\% di cina, hongkong, mauritius, puerto rico, republik korea, dan Singapura, di negara-negara maju kisaran sempit, prevalensi setidaknya 50\% di semua negara dan lebih dari $70 \%$ prevalensi kontrasepsi masih sangat rendah, dengan tidak ada tanda-tanda perubahan substansial, di sebagian besar Afrika selatan sahara dan di bagian asia. Namun, ada bukti peningkatan di beberapa negara di mana tingkat penggunaan telah rendah dan statis sampai saat ini, termasuk Bangladesh, Nepal, dan Pakistan jika diamati dari dekat, fakta 
mengungkapkan bahwa ada banyak ketidakkonsistenan dalam penggunaan kontrasepsi. Sebagian perempuan mengubah metode kontrasepsi yang digunakan dan sebagian lagi memutuskan untuk berhenti menggunakannya.

Survey Data Kesuburan Dunia menunjukkan indikasi kasar tingkat penggantian metode atau penghentian pemakaian kontrasepsi. Hasil survey negara berkembang menunjukkan prosentase bahwa penggunaan metode dari mereka yang pernah digunakan ba adalah $38 \%$ pil, kondom 23\%, 27\% untuk suntikan, $17 \%$ untuk metode penghalang perempuan, IUD 44\%. Data ini tidak mengungkapkan proporsi mereka yang telah berhenti menggunakan salah satu metode tertentu telah beralih ke yang lain dan apa proporsi telah dihentikan sama sekali, tetapi dianggap seluruhnya $50 \%$ untuk setiap kategori.

Tingkat keberlangsungan tampaknya dipengaruhi oleh tingkat pembangunan di suatu negara dan oleh kekuatan dari program KB, sehingga survei kesuburan dunia menemukan bahwa di mana tingkat perkembangan yang tinggi dan upaya Program KB yang kuat, maka rata-rata tingkat keberlangsungan kontrasepsi tinggi. Selain gangguan dalam persediaan atau pelayanan, alasan penghentian kontrasepsi adalah:

a. Tidak bisa menerima efek samping yang ditimbulkan dari kontrasepsi yang mereka gunakan

b. Ketidaknyamanan metode

c. Gangguan hubungan seksual

d. Hilangnya motivasi pribadi, mungkin diperburuk oleh dukungan sosial rendah untuk keluarga berencana

Penaksiran risiko dapat menjadi isu kontroversial. Beberapa orang percaya bahwa satu-satunya ukuran yang relevan keselamatan kontrasepsi adalah risiko absolut terkait dengan metode. (contoh resiko adalah terjadinya kematian pengguna kontrasepsi). Namun, secara luas disepakati bahwa risiko kesehatan dari metode kontrasepsi masih lebih ringan bila dibandingkan dengan risiko kehamilan dan persalinan.

Setiap Negara punya pandangan yang berbeda tentang penerimaan suatu metode kontrasepsi. Analisis mendalam tentang faktor risiko juga harus mempertimbangkan tingkat kegagalan metode, ataupun terkait dengan kehamilan disengaja, termasuk aborsi. Dengan demikian, jika kematian adalah pertimbangan yang paling penting, di negara berkembang dengan angka kematian ibu yang tinggi dan tidak ada aborsi, resiko terendah ditemukan untuk menggunakan metode kontrasepsi yang paling dapat diandalkan. Sebaliknya, di negara maju dengan angka kematian ibu sangat rendah dan aborsi, risiko terendah akan ditemukan dalam menggunakan paling aman, tetapi relatif tidak dapat diandalkan, metode kontrasepsi seperti kondom atau diafragma dengan aborsi sebagai backup dalam kasus kegagalan.

Secara umum, metode kontrasepsi modern lebih aman daripada resiko kehamilan atau melahirkan bagi perempuan di mana saja di dunia, pengecualian pil bagi perempuan berisiko tinggi lebih dari 39 dalam Negara berkembang. Namun, untuk setiap wanita individual keseimbangan antara risiko kontrasepsi dan kehamilan akan berbeda, dan akan tergantung pada faktor-faktor seperti usia, paritas, status gizi dan kesehatan serta pada kondisi kehidupannya, akses untuk perawatan medis dan metode kontrasepsi yang dipilih.

Selanjutnya, komponen dari persamaan risiko yang sering dilupakan adalah fakta bahwa sejumlah metode kontrasepsi modern memiliki tambahan, manfaat kesehatan non kontrasepsi. dengan demikian, kontrasepsi hormonal mengurangi jumlah kehilangan darah pada menstruasi dan dengan demikian mengurangi risiko anemia. Mereka juga telah terbukti menjadi pelindung terhadap resiko bentuk kanker tertentu-dari ovarium dan endometrium dan untuk mengurangi risiko infeksi panggul

\section{SIMPULAN}

Tujuan utama dari program keluarga berencana harus bisa memberikan kekuatan untuk memilih sendiri jumlah dan waktu anak-anak mereka, hal ini, pada saat yang sama, melayani tujuan perencana kesehatan dengan membantu mengurangi risiko melahirkan anak dan untuk menyelamatkan nyawa. Bagaimanapun ketika bergulat dengan tingginya angka kematian ibu, keluarga berencana tidak harus dilihat sebagai pengganti untuk perawatan kebidanan. Tapi ini adalah godaan ketika anggaran kesehatan terbatas dan pilihan harus dibuat, karena sangat jauh lebih mudah untuk mencapai cakupan yang baik dengan layanan keluarga berencana dapat 
mengurangi jumlah perempuan pada risiko kematian akibat kehamilan, hal itu tidak apa-apa untuk mengurangi risiko bagi mereka yang hamil

Peran keluarga berencana dalam memerangi kematian ibu adalah untuk membantu menciptakan kondisi yang sehat untuk melahirkan dan mengurangi risiko kematian terkait kehamilan bagi wanita. ini hanya salah satu bagian dari jawaban komplek untuk masalah yang kompleks

\section{DAFTAR PUSTAKA}

Utomo, B. 1985, Mortalitas: Pengertian dan Contoh Kasus di Indonesia Jakarta: Proyek Penelitian Morbiditas dan Mortalitas Universitas Indonesia

Departemen Kesehatan Rl, 2004, Kajian Kematian lbu dan Anak di Indonesia, Jakarta: Departemen Kesehatan

Depkes, 2004, Badan Penelitian dan Pengembangan Kesehatan, Jakarta: Departemen Kesehatan

Davis, K., 19774, Struktur Sosial dan Fertilitas (Social structure and fertiliy: an analytical framework), Yogyakarta: Lembaga Kependudukan UGM

Robinson, C., 1983, Menuju Teori Fertilitas Terpadu (Toward a unified theory of fertility) ,Yogyakarta: Pusat Penelitian dan Studi Kependudukan UGM

Fakultas Geografi UGM, 2010, Jurnal Kependudukan Indonesia Vol.V. Nomor 1 Tahun 2010

Freedman, R., 1979, Theories of fertility decline: a reappraisal" in Philip $M$. Hauser (ed.), World Population and development: Newyork: Syracuse University Press 